\title{
The Impact of Moral Sensitivities and Professional Values of Nursing Students on Care Perception
}

\section{Hemşirelik Öğrencilerinin Ahlaki Duyarlılıklarının ve Profesyonel Değerlerinin Bakım Algısına Etkisi}

\author{
(D) Diğdem LAFÇI, io Ebru YILDIZ, iD Kübra AKKAYA, id Gamze ÇOLAK
}

Mersin University, Department of Nursing, Mersin, Turkey

\begin{abstract}
Objective: This study was conducted to investigate the effect of nursing students' perceptions of moral sensitivities and the care given by professional values towards the nursing profession.

Methods: Research was approved by Mersin University Clinical Research Ethics Committee and planned as a descriptive study. It was conducted between 1 May and 30 June 2017 with 195 students graduating in the third and fourth grades of the School of Health Nursing Department of a public university. Data were collected with "Individual Identification Form", "Moral Sensitivity Questionnaire (MSQ)', "Nurses' Professional Values Scale (NPVS)" and "Individualized Care Scale-A-Nurse Version (ICSA-Nurse)'.

Results: It was found that $55.4 \%$ of the students did not voluntarily choose the profession, $31.8 \%$ met ethical problems during clinical practice and $38.7 \%$ thought that the problems faced should be solved with the help of the clinical guide. The mean scores of the students from the MSQ, NPVS and ICSA-Nurse forms were as follows; (84.32 \pm 28.32$),(125.17 \pm 34.07),(60.74 \pm 16.35)$. There was a significant positive correlation between the Professional values and the individualized care abilities mean scores $(\mathrm{p}<0.05)$. The mean scores of benevolence and orientation subscales of MSQ were found to be higher in males, and the mean scores of conflict and autonomy subscales of MSQ were found to be higher in 4th grade. "Clinical situation", "personal life situation" and "decisional control over care" mean scores were found to be higher in female students. The mean score of professional values was found to be higher in those who
\end{abstract}

\section{ÖZ}

Amaç: Çalışma, hemşirelik öğrencilerinin ahlaki duyarlılıklarının ve hemşirelik mesleğine yönellik profesyonel değerlerinin, verdikleri bakımı algılamalarına etkisini incelemek amacıyla yapıldı.

Yöntemler: "Mersin Üniversitesi Klinik Araştırmalar Etik Kurulu" tarafından onaylanan ve tanımlayıcı olarak planlanan araştırma, 1 Mayıs-30 Haziran 2017 tarihleri arasında bir devlet üniversitesinin sağlık yüksekokulu hemşirelik bölümü 3. ve 4. sınıflarında öğrenim gören, etik dersini almış gönüllü 195 öğrenci ile yürütüldü. Veriler, "Birey Tanıtım Formu", "Ahlaki Duyarlılık Anketi (ADA)", "Hemşirelerin Profesyonel Değerler Ölçeği (HPDÖ)” ve "Bireyselleştirilmiş Bakım Skalası-A-Hemşire Versiyonu (BBSAHemşire)" ile topland.

Bulgular: Öğrencilerin \%55,4’ünün mesleği isteyerek seçmediği, \%31,8'inin klinik uygulama sırasında etik problem ile karşılaştığı ve \%38,7’sinin karşılaştığı problemleri klinik rehberden yardım alarak çözülmesi gerektiğini düşündüğü belirlendi. Öğrencilerin, ADA, HPDÖ ve BBSA-Hemşire formlarından aldıkları puan ortalamaları sırasıyla; $84,32 \pm 28,32,125,17 \pm 34,07 ; 60,74 \pm 16,35$ 'tir. Profesyonel değerler ile bireyselleştirilmiş bakım becerisi puan ortalamaları arasında pozitif yönde anlamlı bir ilişki saptandı $(\mathrm{p}<0,05)$. Ahlaki duyarlılık için yarar sağlama ve oryantasyon alt puan ortalaması erkeklerde, çatışma ve otonomi ise 4. sınıflardan yüksekti. Bireyselleştirilmiş bakım, klinik durum ve karar verme puan ortalaması kızlarda yüksekti. Profesyonel değerler puan ortalaması mesleği isteyerek seçenlerde, harekete geçme ve güvenlik ise mesleği severek yapanlarda yüksekti.

Address for Correspondence: Diğdem LAFÇı, Mersin University, Department of Nursing, Mersin, Turkey E-mail: lafci@mersin.edu.tr ORCID ID: orcid.org/0000-0001-7199-416X 
wanted to choose the profession, and the means scores of action and safety were found to be higher in those did the profession willingly.

Conclusion: It was concluded that the development of professional value was important for the individualized care skill of the student.

Keywords: Moral sensitivity, nursing students, professional values
Sonuç: Öğrencinin bireyselleştirilmiş bakım becerisi için profesyonel değer gelişiminin önemli olduğu söylenebilir.

Anahtar Sözcükler: Ahlaki duyarlılık, hemşirelik öğrencileri, profesyonel değerler

\section{Introduction}

Care, which is a multidimensional concept, consists of the results of individuals' cultures, values, experiences and their relationships with others (1). It is important for nurses to be aware of the values that guide their personal and professional behaviors in order to provide qualified service to the individuals they care for $(2,3)$. The nurse needs professional values that find verbal expression in ethical codes by creating the philosophy of nursing while explaining/defending the reasons for the individual's behavior and attitudes during care and making decisions when faced with ethical dilemmas (2). The values of nurses guide their interactions with colleagues, other team members and the society, guide them to make decisions about practices and form the basis $(4,5)$.

Professional values help to perceive and evaluate what is right/ wrong, important or less important in professional attitudes and behaviors (6). Professional values and moral sensitivity that predict problem solving and critical thinking skills, which play a primary role in determining the needs of the individual and their family, directly affect the quality of care (7). Quality nursing care is shaped by moral development, which is the process of creating a system of values that the individual can use effectively in society. This development is essential for professional nurses to develop their ability to make decisions in line with moral behavior and ethical codes (8). At the same time, in cases where there is an ethical dilemma that needs to be decided, the moral sensitivity required to recognize and resolve the dilemma is influenced by the personal values of the nurse giving care $(9,10)$.

With the expansion of personal values system in nursing education, which has an important role in the development and shaping of professional values, it is aimed to pattern new professional values into this system. Students can use their skills to reflect these values in professional behaviors through professional work and socialization, including after graduation $(10,2)$. It is observed that nursing students are faced with ethical dilemmas and problems as well as health professionals during clinical practices. Although the ethics course is an integral part of the nursing undergraduate curriculum, students are incapable of resolving and managing ethical dilemmas and problems. Students may experience problems in perceiving ethical problems and dilemmas, in solution-oriented approaches to the problem, and in coping with the problems due to the poor self-confidence, and limited clinical practice experience and ethics education.

In the literature, there are separate studies to determine nursing students' professional values and influencing factors (11-13), ethical sensibilities (14-16), and individualized care perception
(17). However, no study has been found in which students' moral sensibilities and professional values towards nursing profession and individualized care perception are discussed together. For this reason, this study was conducted to examine the effects of nursing students' moral sensibilities and professional values towards nursing profession on their perception of care.

\section{Method}

\section{The Universe and Sample of the Research}

The universe of the descriptive and cross-sectional study consisted of $4533^{\text {rd }}$ and $4^{\text {th }}$ grade students graduating in Nursing Department of a state university where the research was conducted during 2016-2017 academic year spring semester, and the sample of the study consisted of 195 students who agreed to participate in the study, attended the course on 08-19 May 2017 and met the inclusion criteria.

\section{Research Variables}

Moral sensitivity, perception of care and nursing values were dependent variables. Students' age, gender, school grade, and the high school they graduated from were independent variables.

\section{Collection of Data}

"Personal Information Form", "Moral Sensitivity Questionnaire", "Nurses Professional Values Scale" and "Individualized Care Scale-Nurse Version" were used for data collection. The data were collected using face-to-face interview technique. The application of the questionnaire took approximately 15 minutes.

\section{Personal Information Form}

In the Personal Information Form developed by researchers in line with the literature $(18,19)$, there were 18 questions in total about students' descriptive characteristics (age, gender, marital status, high school they graduated from, etc.) and their opinions on ethics (the course they took on ethics, the publication they followed, the situation of encountering ethical dilemma in the practice lessons, ethical problem solving, etc.).

\section{Moral Sensitivity Questionnaire (MSQ)}

The Turkish validity and reliability study of the scale, which was developed by Kim Lützen in 2000 to measure the ethical sensibilities of nurses, was conducted by Tosun in 2005 (20,21). The scale consists of 30 items arranged under six subscales: Autonomy (items 10,12,15,16,21,24 and 27), benevolence (items 2,5,8 and 25), holistic approach (items 1,6,18,29 and 30), conflict (items 9,11 and 14), practice (items 4,17,20 and 28), 
and orientation (items 7,13,19 and 22). It is a seven-point Likert scale. Responses to items in the questionnaire range between 1 (strongly agree) and 7 (strongly disagree). A total of 30-210 points can be obtained from the scale. High score indicates low sensitivity in terms of ethics, low score indicates high sensitivity in terms of ethics. In the adaptation study of the scale in Turkey, Cronbach's alpha value was reported as 0.84 and 0.87 was found in this study.

\section{Nurses Professional Values Scale (NPVS)}

The Turkish validity and reliability study of the scale, which was developed in 2000 by Darlene Weis and Mary Jane Schank, based on the ethical codes of the American Nurses Association, was conducted by Orak in 2005. The scale consists of five subscales and a total of 36 items: Human dignity (11 items), responsibility (9 items), action (8 items), safety (4 items) and autonomy (4 items). The total score obtained from the scale is calculated by summing the scores obtained from 36 items such as human dignity (17-18- 19-28-29-31-32-33-34-35-36), responsibility (6-7-8-9-10-11-13-14-16), action (4-12-15-20 21-22-27-30), safety (1-2-3-5), and autonomy (23-24-25-26). Five-point likert is used as; not important (1), slightly important (2), important (3), very important (4), extremely important (5). A total of 36180 points can be obtained from the scale. High scores indicate that nurses attach more importance to their professional values (17). In this study, Cronbach's alpha value was found to be 0.93 .

\section{Individualized Care Scale-Nurse Version (ICS-Nurse)}

The Individualized Care Scale-Nurse Version was developed by Suhonen et al. in 2007 to evaluate nurses' views about individualized care in the healthcare setting. Adaptation to Turkish population was made by Şendir et al. (23) in 2010. In the first part of the scale, nurses' perceptions of supporting the individuality of patients in their care practices (ICSA-Nurse), and in the second part, perceptions of individualizing patients' care (ICSB-Nurse) are evaluated. The scale consisting of 17 items in 5-point Likert type is scored as "1 = strongly disagree", "2 = partially disagree", " 3 = undecided", " 4 = partially agree", " 5 = completely agree". In this study, the first part that evaluates nurses! perceptions of supporting the individuality of patients in care practices (ICSA-Nurse) was used. The ICSA-Nurse is consisted of 3 subscales: "Clinical situation" (care behaviors aimed at supporting the individuality of sick individuals in issues that include responses to the disease, feelings, feelings, and what the disease means to them), "personal life situation" (care behaviors aimed at supporting the individuality of sick individuals in issues that reflect the beliefs and values of sick individuals, such as habits, activities, preferences, family ties, as well as work and hospital experience) and "decisional control over care" (caring behaviors aimed at supporting the individuality of the sick individuals in issues that reflect the feelings, thoughts, desires of sick individuals and allowing them to have a say in their care and participate in decisions related to their care) (18,24-26). The items included in the subscales are: Clinical situation (A01-A07), personal life situation (A08-A011) and decisional control over care (A12-A17). Item score averages that can be obtained from each part and subscales of the ICSA-Nurse version are at least 1 and at most 5. The high score indicates that nurses generally support the individuality of the patients during their nursing actions. When applying part $\mathrm{A}$ of the scale, nurses are asked to consider their general attitudes about how they support the individuality of the patients in their general care practices (19). In the presented study, Cronbach's alpha value was found to be 0.90 .

\section{Ethical Aspect of the Research}

The study was approved by the "Mersin University Clinical Research Ethics Committee" (2017/142) and the "Mersin University Directorate of İçel Health High School ". The purpose of the study, its duration and what was expected from them were explained to the students in the sample and their written consent was obtained in line with the willingness and voluntary principle.

\section{Statistical Analysis}

Statistical analysis of the data was carried out using the SPSS 20.0 (Statistical Package for Social Science for Windows) package program. In continuous measurements; arithmetic mean, standard deviation, in categorical measurements; numbers and percentages were used. For comparison of 2 independent groups, and 3 or more groups; "Student's t-test" and "One-Way Anova" were used when the parametric distribution prerequisite was met, and "Kruskal-Wallis" and "Mann-Whitney U Test" were used when the parametric distribution prerequisite was not met. Relationships between variables were examined with the "Pearson Correlation Coefficient" and the reliability of the scales with the "Cronbach's Alpha" coefficient. The results were evaluated at a significance level of $\mathrm{p}<0.05$ at a $95 \%$ confidence interval.

\section{Results}

The average age of the students was $21.95 \pm 1.44$ years. It was determined that $56.9 \%$ of them were girl, $42.6 \%$ were 4 th grade students and $55.4 \%$ were graduates of science and anatolian high schools, and $62.1 \%$ lived in the Mediterranean region. It was determined that $48.7 \%$ of the students had clinical practice on average $1.84 \pm 0.98$ days per week during the 14 -week education period, including in the pediatric service. It was found that $44.6 \%$ chose the profession willingly, $65.6 \%$ liked to go/willingly went to clinical and field practice, $100 \%$ took ethics lessons, $86.2 \%$ did not follow any publications related to ethics, $52.3 \%$ did not have information about the ethics committee of the hospital where they went for clinical and field practice, $31.8 \%$ encountered ethical problems during the practice and $38.7 \%$ solved the problems they encountered with help (Table 1).

When the mean scores of the students from the scales were examined; the mean score of MSQ was $84.32 \pm 28.32$, the mean NPVS score was $125.17 \pm 34.07$, and the mean ICSA-Nurse score was $3.57 \pm 0.96$ (Table 1 ).

Findings regarding the comparison of MSQ score averages of students according to their introductory characteristics are shown in Table 2. 
Table 1. Findings regarding students' demographic features, their information on ethics and total scores of MSQ, NPVS, ICSA-Nurse Demographic features

\section{Age}

Gender

Female

Male

Mean \pm SD

Grade

$3^{\text {rd }}$ grade

$4^{\text {th }}$ grade

$21.95 \pm 1.44$

N

High school from where you graduated

Health vocational high school

High school

Private high school

Science/Anatolian high school

Other

Geographical region where you grew up

East

West

South

\section{Central Anatolia}

Status of choosing the profession willingly

Yes

No

Knowledge on ethics

\section{Service of clinical practice}

Gynecology/maternity service

108

Pediatrics service

Psychiatry service

Public health

Participating in clinical practice with love/willingness

Yes

No

Status of following publications related to ethics

Yes

The state of being aware of the existence of an ethics committee in the institution where you practiced

No

I do not know

The situation of encountering an ethical problem during practice

Yes

The situation of solving the ethical problem encountered during practice*

I thought it should be resolved

I thought I should get help

I thought it couldn't be solved 
Table 2. Students' moral sensitivity according to their demographic characteristics and their knowledge on ethics Moral Sensitivity Questionnaire (MSQ)

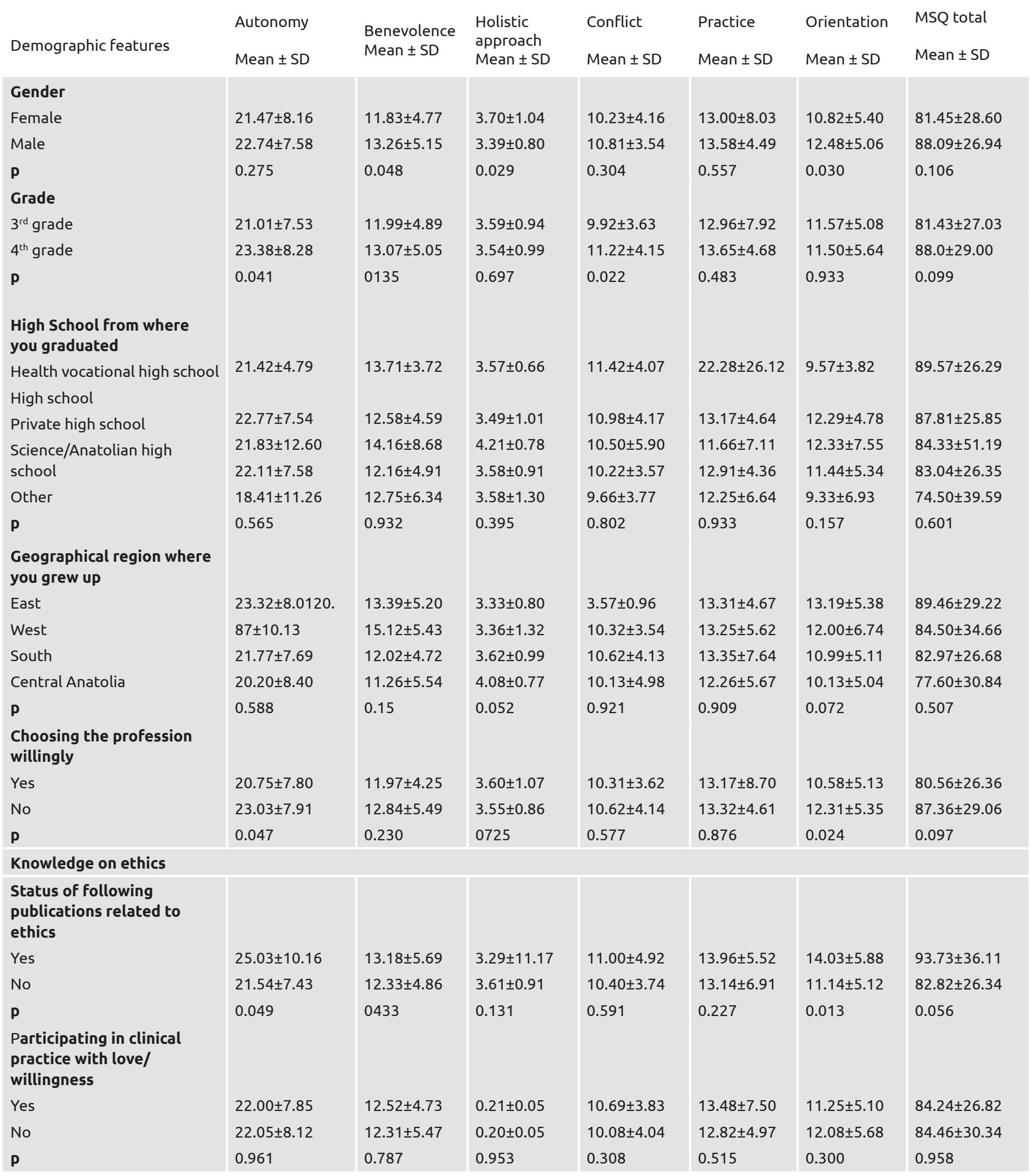


Table 2. contiuned

\begin{tabular}{|c|c|c|c|c|c|c|c|}
\hline Service of clinical pract & & & & & & & \\
\hline $\begin{array}{l}\text { Gynecology/maternity } \\
\text { service }\end{array}$ & $23.50 \pm 5.83$ & $13.15 \pm 4.13$ & $3.51 \pm 0.97$ & $10.34 \pm 3.66$ & $14.03 \pm 3.61$ & $13.88 \pm 4.99$ & $90.26 \pm 22.59$ \\
\hline Pediatrics service & $21.00 \pm 7.66$ & $11.84 \pm 4.87$ & $3.65 \pm 0.92$ & $10.10 \pm 3.65$ & $13.00 \pm 8.38$ & $11.17 \pm 5.01$ & $80.94 \pm 26.95$ \\
\hline Psychiatry service & $24.83 \pm 9.18$ & $13.81 \pm 5.68$ & $3.63 \pm 1.00$ & $11.79 \pm 4.29$ & $14.20 \pm 4.68$ & $12.189 \pm 6.02$ & $92.54 \pm 32.61$ \\
\hline Public health & $19.96 \pm 7.43$ & $11.83 \pm 4.67$ & $3.29 \pm 0.98$ & $9.93 \pm 4.09$ & $12.06 \pm 5.27$ & $9.80 \pm 4.84$ & $78.00 \pm 26.20$ \\
\hline $\mathbf{p}$ & 0.048 & 0.161 & 0.174 & 0.228 & 0.060 & 0.021 & 0.113 \\
\hline Yes & $20.95 \pm 8.36$ & $11.00 \pm 4.43$ & $3.77 \pm 1.073$ & $10.43 \pm 4.24$ & $13.64 \pm 11.00$ & $10.06 \pm 4.82$ & $80.06 \pm 27.64$ \\
\hline No & $24.71 \pm 7.96$ & $14.08 \pm 5.13$ & $3.10 \pm 0.84$ & $10.77 \pm 3.91$ & $13.97 \pm 4.91$ & $14.13 \pm 5.30$ & $94.68 \pm 30.67$ \\
\hline Yes & $22.68 \pm 7.52$ & $12.41 \pm 5.29$ & $3.60 \pm 0.85$ & $11.00 \pm 4.16$ & $13.30 \pm 4.15$ & $11.87 \pm 5.34$ & $85.95 \pm 27.17$ \\
\hline No & $21.70 \pm 8.11$ & $12.46 \pm 4.84$ & $3.55 \pm 1.01$ & $10.24 \pm 3.78$ & $13.23 \pm 7.66$ & $11.39 \pm 5.31$ & $83.55 \pm 28.48$ \\
\hline $\mathbf{p}$ & 0.427 & 0.948 & 0.752 & 0.215 & 0.944 & 0.558 & 0.583 \\
\hline $\begin{array}{l}\text { The situation of solving } \\
\text { the ethical problem } \\
\text { encountered during } \\
\text { practice* }\end{array}$ & & & & & & & \\
\hline I solved it on my own & $22.95 \pm 9.09$ & $12.18 \pm 5.55$ & $3.49 \pm 0.95$ & $10.00 \pm 4.89$ & $13.31 \pm 4.94$ & $11.72 \pm 5.33$ & $85.95 \pm 32.80$ \\
\hline
\end{tabular}

"Autonomy" subscale average score was found to be higher in grade 4 students who chose their profession involuntarily, followed ethical publications, and practiced in an institution that did not have an ethics committee $(p<0.05)$.

It was found that the mean score of the "Benevolence" subscale was higher in male students who had a practice in an institution without an ethics committee and the mean score of the "Holistic approach" subscale was higher in female students $(\mathrm{p}<0.05)$.

It was found that the mean score of the "Conflict" subscale was higher in $4^{\text {th }}$ grade students and the mean score of the "Orientation" subscale was found to be higher in male students who chose their profession involuntarily, followed up ethicsrelated publications, and did not have an ethical institution in the service where they went for practice $(\mathrm{p}<0.05)$.

It was observed that there was no statistically significant difference between the students' high school where they graduated from, the geographical region where they grew up, the area where they went for practice, the state of going to practice with love/ willingness, the situation of experiencing ethical problems and the situation of solving ethical problem encountered, and mean scores of MSQ and its subscales ( $\mathrm{p}>0.05)$.

Findings regarding the comparison of the introductory characteristics of the students and the mean scores of NPVS are shown in Table 3.

It was determined that "Human dignity" subscale mean score was higher in students who chose their profession willingly, followed publications on ethics, went to an institution with an ethics committee for practice, and solved the ethical problem they encountered during the practice with help $(\mathrm{p}<0.05)$.

It was found that "Responsibility" subscale mean score was higher in the students who chose their profession willingly and went to an institution with an ethics committee for practice $(\mathrm{p}<0.05)$.

It was observed that "Action" and "Safety" subscales mean scores were higher in the students who chose their profession voluntarily, went to practice lovingly/willingly, followed ethical publications, and practiced in an institution with an ethics committee $(\mathrm{p}<0.05)$. 
Table 3. Students' demographic characteristics and professional values according to their knowledge on ethics Nurses Professional Values Scale (NPVS)

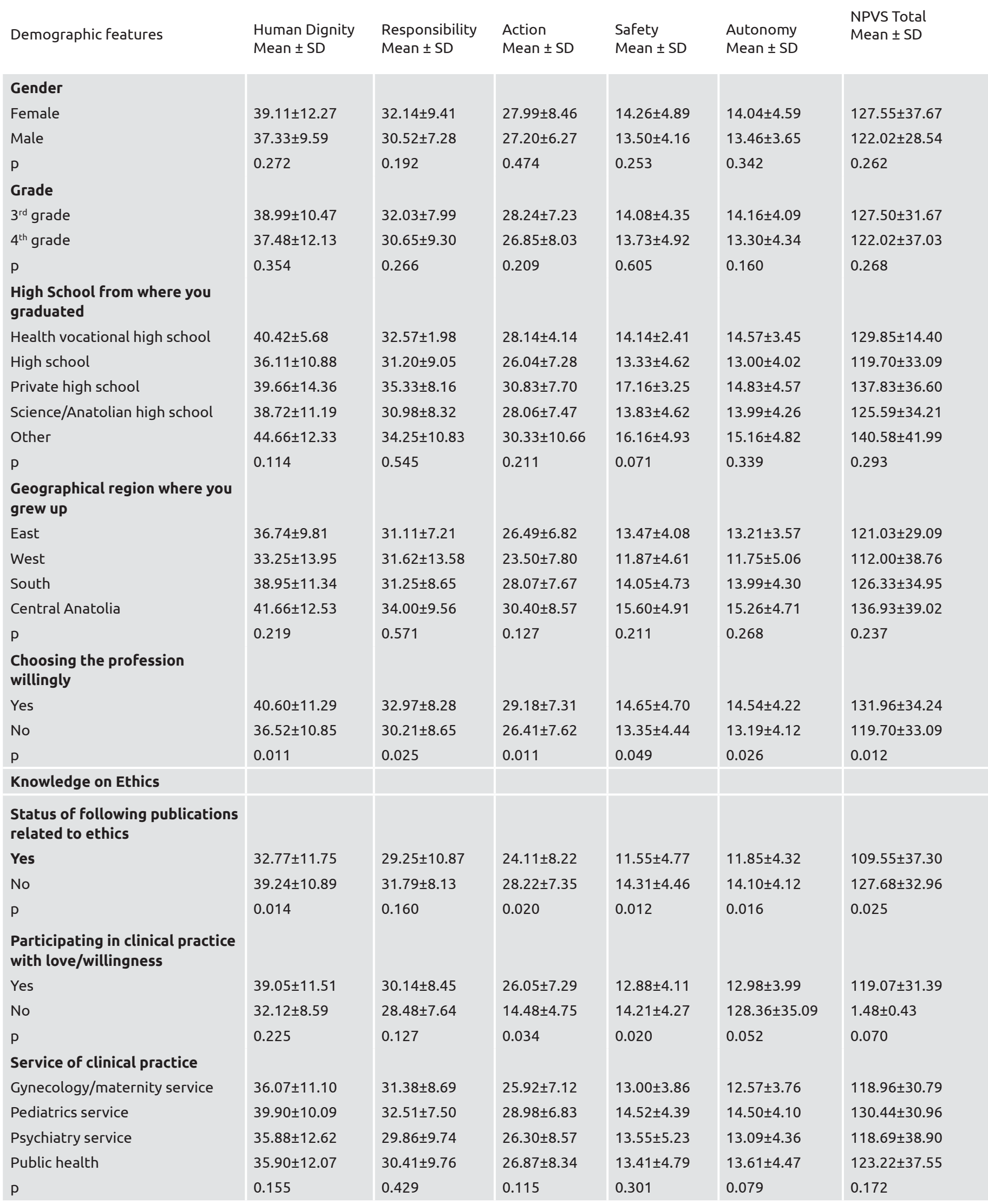


Table 3. contiuned

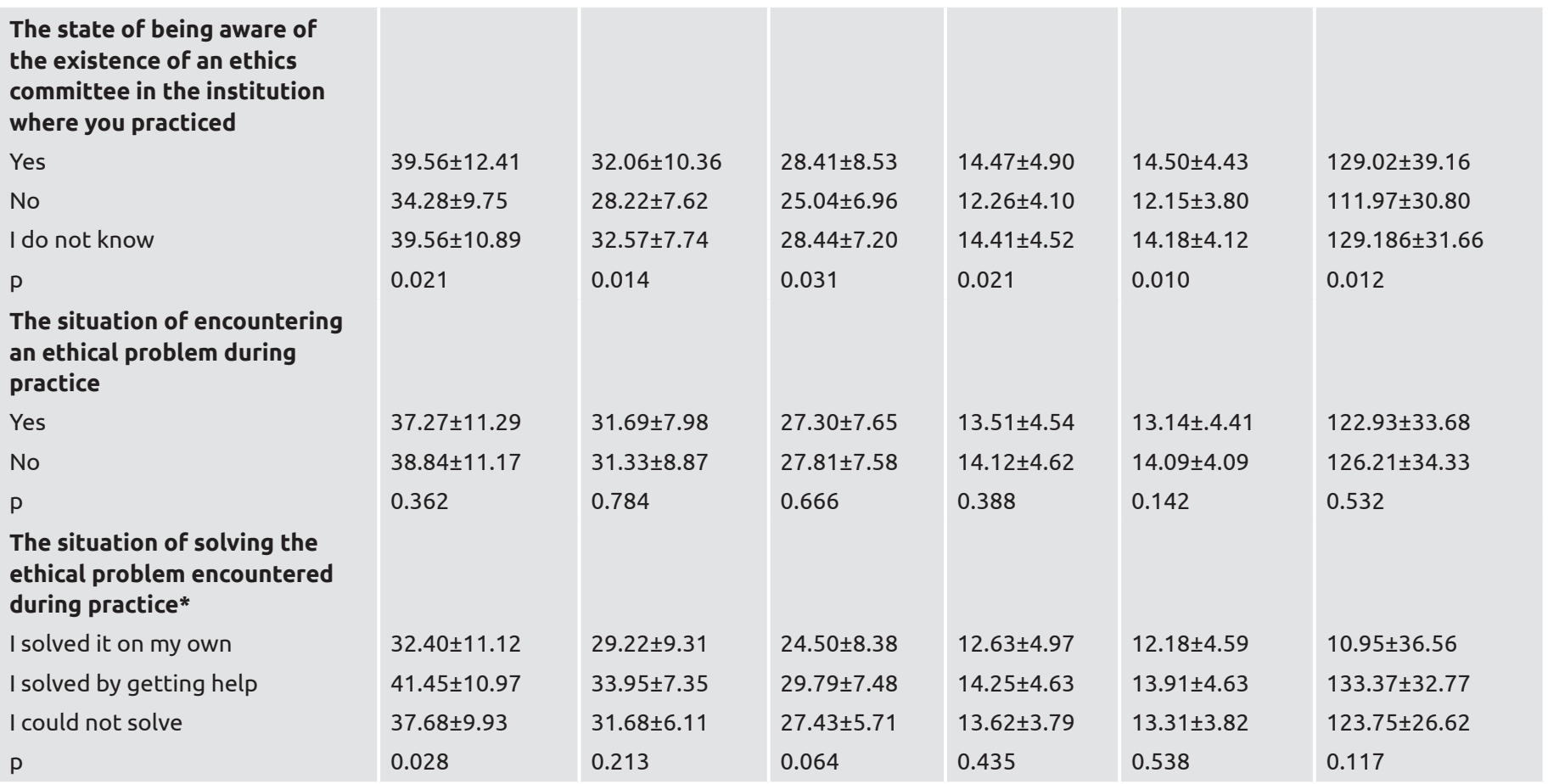

It was determined that "Autonomy" subscale mean score was higher in students who chose their profession voluntarily, followed publications on ethics, and had an ethics committee in the institution where they went for practice $(<0.05)$.

It was observed that there was no statistically significant difference between the students' gender, grade, high school they graduated from, the geographical region where they grew up, the area where they practiced, and encountering ethical problems in practice in terms of NPVS and its subscales mean scores ( $p>0.05$ ).

The findings regarding the comparison of the introductory characteristics of the students and the ICSA-Nurse mean scores are shown in Table 4.

It was observed that "Clinical situation" subscale mean score was higher in female students who grew up in Central Anatolia and practiced in an institution with an ethics committee and that "Personal life situation" subscale was higher in male students $(\mathrm{p}<0.05)$.

It was observed that the mean score of the "Decisional control over care" subscale was higher in female students who were practicing in an institution with an ethics committee $(\mathrm{p}<0.05)$.

It was observed that there was no statistically significant difference between the students' grade, the high school they graduated from, the status of willingly choosing the profession, the area of practice, the situation of going to practice with love/ willingness, the status of following ethical publications, the situation of encountering ethical problems in practice and the the situation of solving ethical problem in terms of ICSA-Nurse and its subscales score means ( $\mathrm{p}>0.05)$.
The correlation analysis results of the students' age, weekly clinical practice days, moral sensitivity, professional values, individualized care scales subscales mean scores are shown in Table 4.

There was a significant negative correlation between the students' mean age and their personal life situation subscale score of ICSA-Nurse $(\mathrm{p}=0.024)$. A positive significant correlation was determined between the mean number of days in weekly clinical practice and the mean scores of "autonomy" and "conflict" subscales, which was subscales of MSQ $(\mathrm{p}<0.05)$.

There were significant negative correlations found between the mean score of holistic approach subscale of the MSQ and the overall total of the NPVS and the mean scores of human dignity, responsibility, action, safety, autonomy subscales of the NPVS $(\mathrm{p}<0.001)$ and the mean scores of "clinical situation", "personal life situation" and "decisional control over case" subscales of the ICSA-Nurse $(p<0.001)$. There were significant negative correlations found between the mean score of orientation subscale of the MSQ and the overall total of the NPVS and the mean scores of human dignity, action, safety, autonomy subscales of the NPVS $(p<0.05)$ and the overall total of the ICSA-Nurse, and the mean scores of "clinical situation", "personal life situation" and "decisional control over case" subscales of the ICSA-Nurse $(\mathrm{p}<0.05)$. A positive significant relationship was found between the overall total $f$ the NPVS and the subscales of human dignity, responsibility, action, safety, autonomy, and the overall total of the ICSA-Nurse, and the mean scores of "clinical situation", "personal life situation" and "decisional control over case" subscales of the ICSA-Nurse $(\mathrm{p}<0.001)$. 
Table 4. Individualized care perceptions according to students' demographic characteristics and their knowledge on ethics

\begin{tabular}{|c|c|c|c|c|}
\hline \multirow[b]{2}{*}{ Demographic features } & \multicolumn{3}{|c|}{ Individualized Care Scale-A-Nurse Version (ICSA-Nurse) } & \multirow{2}{*}{$\begin{array}{l}\text { ICSA-nurse total } \\
\text { Mean } \pm \text { SD }\end{array}$} \\
\hline & $\begin{array}{l}\text { Clinical situation } \\
\text { Mean } \pm \text { SD }\end{array}$ & $\begin{array}{l}\text { Personal life } \\
\text { Mean } \pm \text { SD }\end{array}$ & $\begin{array}{l}\text { Deciding } \\
\text { Mean } \pm \text { SD }\end{array}$ & \\
\hline \multicolumn{5}{|l|}{ Gender } \\
\hline Female & $1.51 \pm 0.43$ & $0.85 \pm 0.24$ & $1.32 \pm 0.43$ & $0.21 \pm 0.06$ \\
\hline Male & $1.39 \pm 0.36$ & $0.80 \pm 0.19$ & $1.19 \pm 0.29$ & $0.20 \pm 0.04$ \\
\hline p & 0.042 & 0.102 & 0.017 & 0.029 \\
\hline $3^{\text {rd }}$ grade & $1.45 \pm 0.39$ & $0.85 \pm 0.21$ & $1.28 \pm 0.41$ & $3.59 \pm 0.94$ \\
\hline $4^{\text {th }}$ grade & $1.47 \pm 0.42$ & $0.81 \pm 0.24$ & $1.24 \pm 0.35$ & $3.54 \pm 0.99$ \\
\hline p & 0.677 & 0.270 & 0.495 & 0.697 \\
\hline \multicolumn{5}{|c|}{ High School from where you graduated } \\
\hline Health vocational high school & $1.43 \pm 0.25$ & $0.83 \pm 0.18$ & $1.30 \pm 0.23$ & $3.57 \pm 0.66$ \\
\hline Other & $1.49 \pm 0.57$ & $0.81 \pm 0.28$ & $1.27 \pm 0.47$ & $3.58 \pm 1.30$ \\
\hline$p$ & 0.235 & 0.495 & 0.563 & 0.395 \\
\hline \multicolumn{5}{|c|}{ Geographical region where you grew up } \\
\hline East & $1.36 \pm 0.34$ & $0.77 \pm 0.20$ & $1.19 \pm 0.29$ & $3.33 \pm 0.80$ \\
\hline West & $1.20 \pm 0.39$ & $0.74 \pm 0.24$ & $1.41 \pm 0.96$ & $3.60 \pm 1.32$ \\
\hline South & $1.49 \pm 0.42$ & $0.84 \pm 0.23$ & $1.27 \pm 0.36$ & $3.62 \pm 0.99$ \\
\hline Central Anatolia & $1.72 \pm 0.31$ & $0.96 \pm 0.20$ & $1.38 \pm 0.31$ & $4.08 \pm 0.77$ \\
\hline $\mathrm{p}$ & 0.003 & 0.010 & 0.227 & 0.052 \\
\hline \multicolumn{5}{|c|}{ Choosing the profession willingly } \\
\hline Yes & $1.31 \pm 0.45$ & $0.75 \pm 0.25$ & $1.22 \pm 0.62$ & $3.29 \pm 1.17$ \\
\hline No & $1.48 \pm 0.39$ & $0.84 \pm 0.22$ & $1.27 \pm 0.33$ & $3.61 \pm 0.91$ \\
\hline$p$ & 0.056 & 0.060 & 0.145 & 0.131 \\
\hline \multicolumn{5}{|c|}{$\begin{array}{l}\text { Participating in clinical practice with love/ } \\
\text { willingness }\end{array}$} \\
\hline Yes & $1.43 \pm 0.43$ & $0.83 \pm 0.23$ & $1.26 \pm 0.36$ & $3.57 \pm 1.00$ \\
\hline No & $1.43 \pm 0.36$ & $0.84 \pm 0.20$ & $1.28 \pm 0.42$ & $3.56 \pm 0.88$ \\
\hline$p$ & 0.444 & 0.768 & 0.710 & 0.953 \\
\hline \multicolumn{5}{|l|}{ Service of clinical practice } \\
\hline Gynecology/maternity service & $1.39 \pm 0.37$ & $0.78 \pm 0.20$ & $1.33 \pm 0.56$ & $3.51 \pm 0.97$ \\
\hline Pediatrics service & $1.49 \pm 0.40$ & $0.87 \pm 0.21$ & $1.28 \pm 0.34$ & $3.65 \pm 0.92$ \\
\hline Psychiatry service & $1.50 \pm 0.44$ & $0.83 \pm 0.23$ & $1.28 \pm 0.35$ & $3.63 \pm 1.00$ \\
\hline Public health & $1.38 \pm 0.40$ & $0.75 \pm 0.25$ & $1.16 \pm 0.34$ & $3.29 \pm 0.98$ \\
\hline$p$ & 0.281 & 0.037 & 0.350 & 0.174 \\
\hline
\end{tabular}


Table 4. contiuned

\begin{tabular}{|c|c|c|c|c|}
\hline \multicolumn{5}{|c|}{$\begin{array}{l}\text { The state of being aware of the existence of } \\
\text { an ethics committee in the institution where } \\
\text { you practiced }\end{array}$} \\
\hline Yes & $1.55 \pm 0.46$ & $0.87 \pm 0.25$ & $1.33 \pm 0.38$ & $3.77 \pm 1.07$ \\
\hline No & $1.26 \pm 0.35$ & $0.73 \pm 0.20$ & $1.10 \pm 0.32$ & $3.10 \pm 0.84$ \\
\hline I do not know & $1.50 \pm 0.38$ & $0.86 \pm 0.21$ & $1.31 \pm 0.39$ & $3.68 \pm 0.89$ \\
\hline$p$ & 0.001 & 0.002 & 0.003 & 0.001 \\
\hline \multicolumn{5}{|c|}{$\begin{array}{l}\text { The situation of encountering an ethical } \\
\text { problem during practice }\end{array}$} \\
\hline Yes & $1.48 \pm 0.39$ & $0.85 \pm 0.21$ & $1.26 \pm 0.31$ & $3.60 \pm 0.85$ \\
\hline No & $1.45 \pm 0.41$ & $0.82 \pm 0.23$ & $1.27 \pm 0.41$ & $3.55 \pm 1.01$ \\
\hline$p$ & 0.675 & 0.462 & 0.974 & 0.752 \\
\hline \multicolumn{5}{|c|}{$\begin{array}{l}\text { The situation of solving the ethical problem } \\
\text { encountered during practice* }\end{array}$} \\
\hline I solved it on my own & $1.47 \pm 0.44$ & $0.81 \pm 0.23$ & $1.21 \pm 0.33$ & $3.49 \pm 0.95$ \\
\hline I solved by getting help & $1.53 \pm 0.34$ & $0.91 \pm 0.18$ & $1.34 \pm 0.27$ & $3.79 \pm 0.73$ \\
\hline I could not solve & $1.41 \pm 0.37$ & $0.81 \pm 0.21$ & $1.24 \pm 0.32$ & $3.47 \pm 0.88$ \\
\hline $\mathrm{p}$ & 0.478 & 0.251 & 0.297 & 0.392 \\
\hline
\end{tabular}

\section{Discussion}

Professional values and caring accordingly are as important as moral sensitivity in making ethical decisions (5). In this direction, the findings obtained from the study conducted with the aim of examining the effect of the moral sensitivity and professional values of nursing students on the perception of care were discussed below in line with the literature knowledge and similar studies.

It was determined that the nursing students encountered ethical problems during the practice and thought that the problems they encountered should be solved with the help of the clinical guide. Ethical dilemmas arise from confusion between two values during clinical practice or in a situation where a decision has to be made. In value conflict, a decision should be made in line with ethical principles $(27,28)$. In the studies conducted by Gül et al. (28) with nursing students and by Aydin et al. (29) with senior midwifery students, it was reported that the students could not make decisions in line with the ethical principles due to the lack of clinical experience. In the studies conducted by Aksu and Akyol (30) with nurses working in the clinic and by Dikmen (31) with nurses working in the intensive care unit, it was stated that more than half of the nurses had problems in making the right decisions and finding solutions to ethical dilemmas. The results of the studies are similar to the findings of the study, and it is thought to be due to the limited experience in clinical practice and insufficent ethics education of the students.

It is thought that the reason why the students' level of moral sensitivity is at a medium level is due to the opportunity to observe the ethical problems between patients and nurses during the four years of their university education and their high awareness due to taking the ethics course. Similarly, in studies conducted with nursing students in the literature, it has been reported that the moral sensitivity of nursing students is moderate $(29,32,33)$. In the study by Selçuk and Demir (34) and Aydın et al. (29), it was stated that moral sensitivity was low, whereas in the study of Kim et al. (35), $4^{\text {th }}$ grade students had higher moral sensitivity.

It is emphasized that knowing the qualifications and working conditions of the profession and then willingly choosing the profession facilitate the adoption of professional values that form the basis of the attitudes and behaviors specific to the profession and to reflect them on their behaviors (17). Professional values are high in students who willingly choose the profession and go to clinical and field practice fondly. In the study in which Karamanoğlu et al. (36) examined the professional values of nurses working in surgical clinics, it was determined that nurses who loved their profession had higher professional values. In the study by Beydağ and Arslan (37) examining the factors affecting the professionalism of midwives-nurses working in obstetrics clinics, it was reported that the professionalism level of nursesmidwives who did not intend to change their profession was higher.

Having knowledge about laws and professional ethical codes, clarifying their individual values and beliefs and developing their philosophy, and adopting ethical principles are important factors that can guide nurses to make the best decision when they face an ethical dilemma (17). According to the mean orientation score, one of the subscales of the MSQ; it was determined that the students were insensitive to the importance of individuality in patient care, did not reflect the physician-nurse-patient cooperation and professional values to their care practices, and did not care about patient participation in care and treatment. 


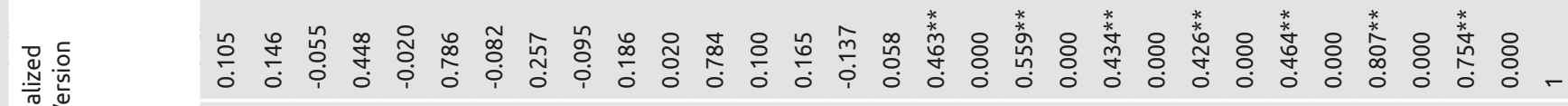

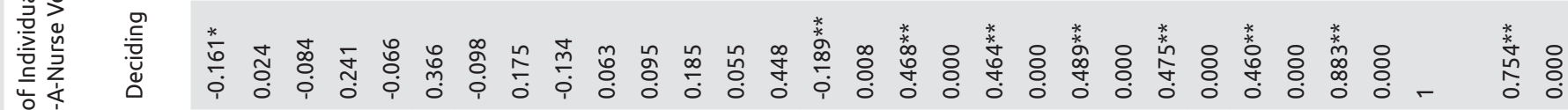

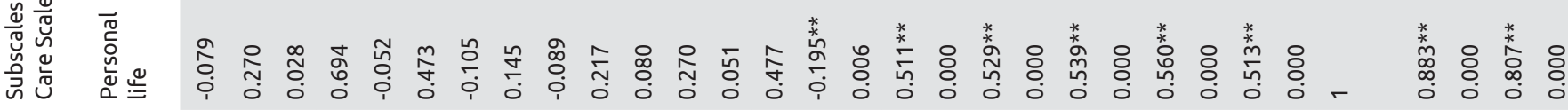

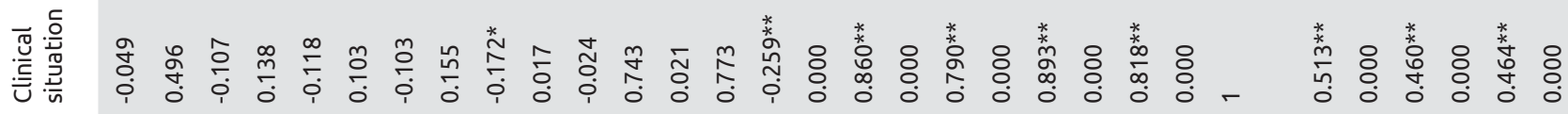

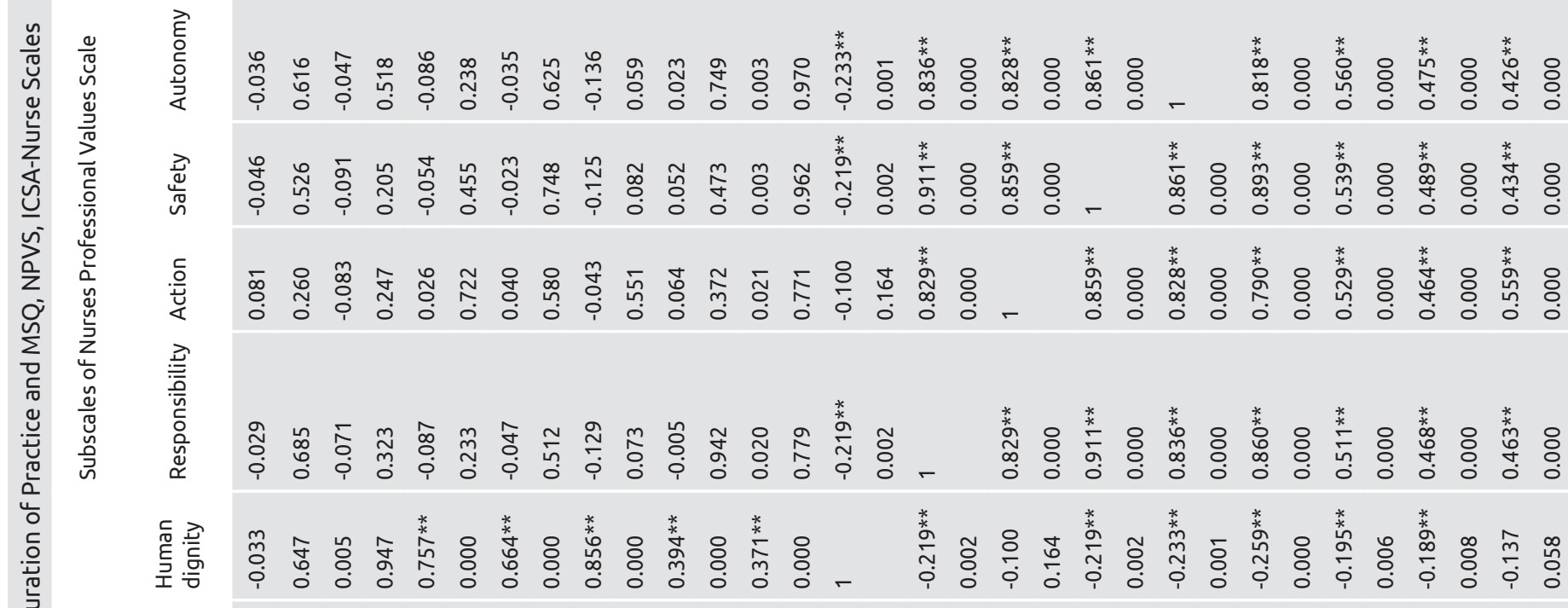
든

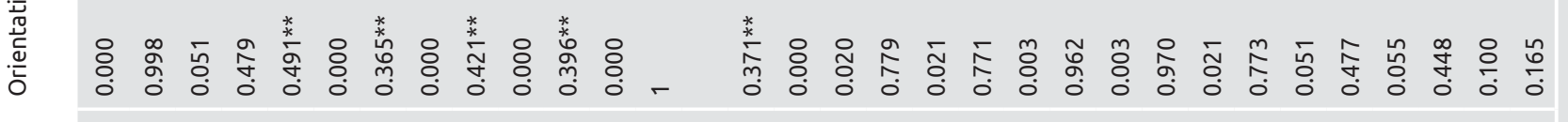

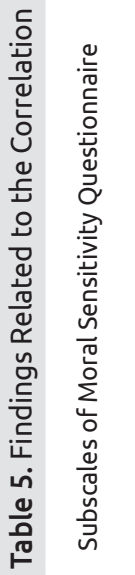

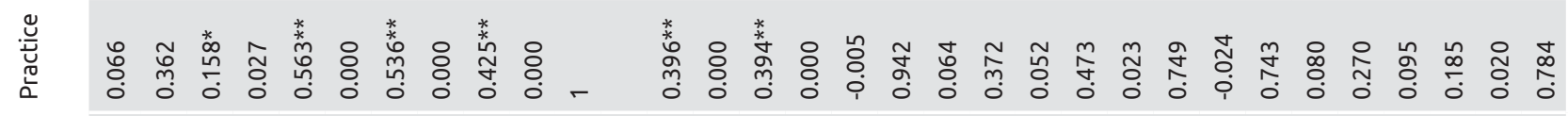

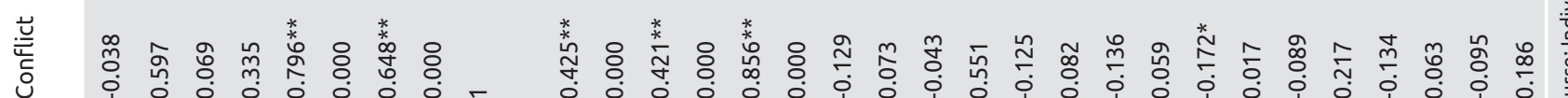

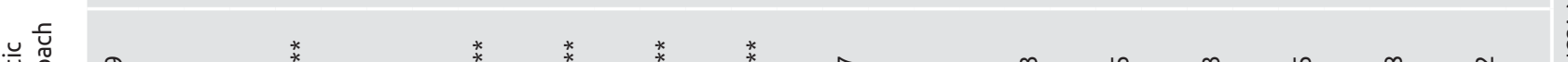

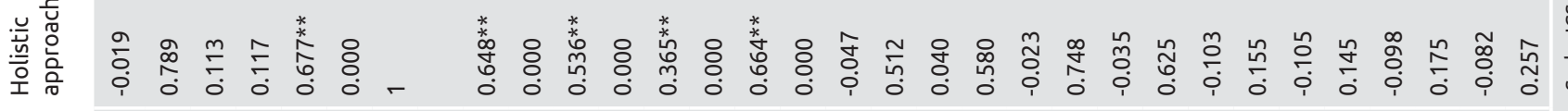
军

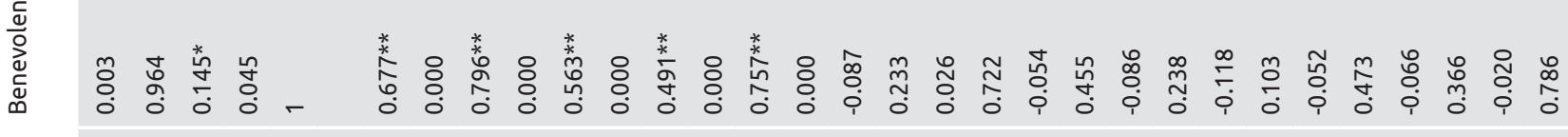

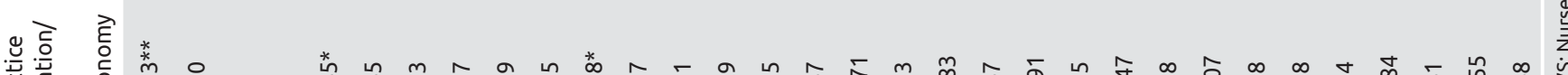

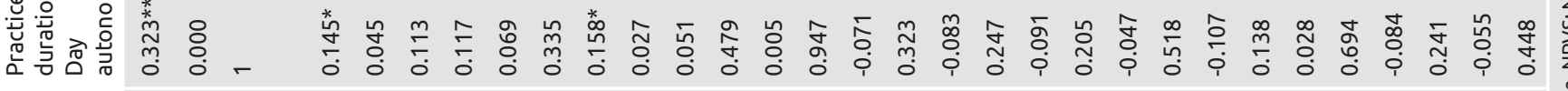

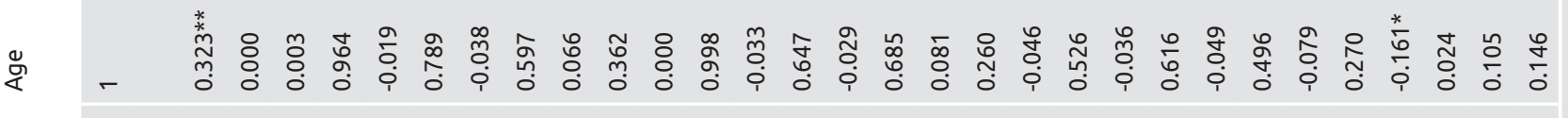
-

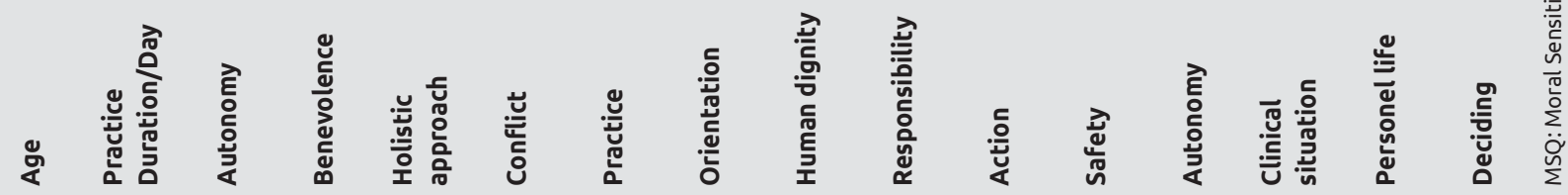


Therefore, this situation shows that among the professional values of the students, human dignity, action, safety and autonomy values and individualized care perceptions are weak. Similarly, Tazegün and Çelebioğlu (38) emphasized in their study that the factors affecting the level of ethical sensitivity of pediatric nurses were influenced by the value systems of nurses.

The mean scores of the ICSA-Nurse and its subscales, "clinical situation" and "decisional control over case" were found to be significantly higher in female students. In line with this result, it is concluded that because women understand the individuals they care for as part of their maternal instinct and respond with compassion, female students support individualized care in issues that include the reactions of sick individuals to illness, their feelings, thoughts and the meaning of the illness for them and that they care about patients having a say in their care and that they enable them to participate in decisions about their care. Lee et al. (39) found a difference in favor of female colleagues in some caring behaviors in terms of gender differences. Contrary to this result, in different studies $(18,40)$ examining nurses' perceptions of individualized care, it was observed that there was no statistically significant difference between gender and individualized care perception.

The discipline of nursing focuses on the philosophy of humanistic and holistic care by treating the individual with a holistic approach that evaluates the individual with his or her family, close and wide environment (19). Care is an appropriate process for the patient's values and expectations to conflict with the nurses' own values and judgments (41). It was observed that the students with poor professional value perceptions could not evaluate individuals in the holistic approach philosophy within the framework of their moral sensitivity, and therefore their individualized care perception was also weak.

It was observed that students with high professional value perception also had a high perception of individualized care. Students with a high perception of professional value also had a high perception of individualized care. According to the philosophy of the nursing profession, which directs care decisions and actions with professional value judgments, the individual is a unique entity with honor, dignity, individuality, values, beliefs and attitudes. The realization of these beliefs, attitudes and values adopted by nurses in the field of practice is expressed as individualized care (17).

\section{Study Limitations}

Since this research was conducted in third and fourth grade nursing students graduating in one university, the findings could not be generalized to all nursing students in Turkey. Conducting the study only with nursing students and not with health professionals, using scales in data collection that limited the responses of students to the expressions contained in the scales were other limitations. Therefore, there were limitations in terms of the quantitative research method used in the study and the findings obtained.

\section{Conclusion}

According to the findings of the study, the moral sensitivity levels of nursing students were found to be similar to the levels of moral sensitivity found in many previous studies. Students who did their profession with love/willingly had a higher level of moral sensitivity, and in parallel, it could be said that professional value development was important for students' individualized care skills. In addition, it can be said that distributing ethicsrelated courses into four years of Nursing Education will be useful in terms of raising students' awareness. It is thought that including activities that will make students recognize their own value systems and gain positive personal and professional values, and increasing case studies in order to improve their skills regarding ethical decision-making processes in clinical practice will positively affect students' ethical sensitivities.

\section{Ethics}

Ethics Committee Approval: The study was approved by the "Mersin University Clinical Research Ethics Committee" (2017/142) and the "Mersin University Directorate of İçel Health High School”.

Peer-review: Externally peer reviewed.

\section{Authorship Contributions}

Concept: D.L., E.Y., Design: D.L., E.Y., Data Collection or Processing: D.L., E.Y., K.A., G.Ç., Analysis or Interpretation: D.L., E.Y., K.A., G.Ç., Literature Search: D.L., E.Y., K.A., G.Ç., Writing: D.L., E.Y., K.A., G.Ç.

Conflict of Interest: No conflict of interest was declared by the authors.

Financial Disclosure: The authors declared that this study received no financial support.

\section{References}

1. Weis D, Schank MJ. Professional values: key to professional development. J Prof Nurs 2002;18:271-5.

2. Babadağ K. Profesyon/Meslek. Hemşirelik ve Değerler. Ankara: Alter Yayıncılık; 2010.p.16-7.

3. Sabancıŏ̆ulları S, Doğan S. Profesyonel kimlik gelişimi ve hemşirelik. J Anatol Nurs Health Sci 2012;15:275-82.

4. Vezeau TM. Teaching professional values in a BSN program. Int J Nurs Educ Scholarsh 2006;3:10-31.

5. Kaya H, Işı B B, Şenyuva E, Kaya N. Hemşirelik öğrencilerinin bireysel ve profesyonel değerleri. J Anatol Nurs Health Sci 2012;15:18-26.

6. Altun İ. Etik ve Değerler. In: Atabek Aşıı T, Karadağ A, editors. Hemşirelik Esasları: Hemşirelik Bilimi ve Sanatı İçinde. İstanbul: Akademi Basın ve Yayıncılık; 2016.p.114-22.

7. Leners DW, Roehrs C, Piccone AV. Tracking the development of professional values in undergraduate nursing students. J Nurs Educ 2006;45:504-11. 
8. İpek Çoban G, Türer S. Ahlaki Gelişim ve Hemşirelik. Gümüşhane Üniv Sağ Bil Derg 2014;3:948-58.

9. Jormsri P, Kunaviktikul W, Ketefian S, Chaowalit A. Moral competence in nursing practice. Nurs Ethics 2005;12:582-94.

10. Keskin G, Yıldırım GÖ. Hemşirelerin kişisel değerlerinin ve iş doyumlarının incelenmesi. Ege Üniv Hemş Yüksekokulu Derg 2006;22:119-33.

11. Alfred D, Yarbrough S, Martin P, Mink J, Lin YH, Wang LS. Comparison of professional values of Taiwanese and United States nursing students. Nurs Ethics 2013;20:917-26.

12. Karadağlı F. Hemşirelik öğrencilerinin profesyonel değer algıları ve etkileyen faktörler. Mersin Üniv Sağ Bil Derg 2016;9:81-91.

13. Dönmez RO, Özsoy S. Factors influencing development of professional values among nursing students. Pak J Med Sci 2016;32:988-93.

14. Ahn SH, Yeom HA. Moral sensitivity and critical thinking disposition of nursing students in Korea. Int J Nurs Pract 2014;20:482-9.

15. Borhani F, Abbaszadeh A, Hoseinabadi-Farahani MJ. Moral sensitivity and its dimensions in Iranian nursing students. J Med Ethics Hist Med 2016;9;19.

16. Akça NK, Şimşek N, Arslan DE, Şentürk S, Akça D. Moral sensitivity among senior nursing students in Turkey. Int J Caring Sci 2017;10;1031-9.

17. Can Ş, Acaroğlu R. Hemşirelerin mesleki değerlerinin bireyselleştirilmiş bakım algıları ile ilişkisi. İstanbul Üniv Florence Nightingale Hemş Derg 2013;23:32-40.

18. Suhonen R, Gustafsson ML, Katajisto J, Välimäki M, Leino-Kilpi H. Nurses' perceptions of individualised care. J Adv Nurs 2010;66:103546.

19. Acaroğlu R, Şendir M. Bireyselleştirilmiş bakımı değerlendirme skalaları. İstanbul Üniv Florance Nightingale Hemş Derg 2012;20:106.

20. Lützén K, Johansson A, Nordström G. Moral sensitivity: Some differences between nurses and physicians. Nurs Ethics 2010;7:52030.

21. Tosun H. Sağlık uygulamalarında deneyimlenen etik ikilemlere karşı hekim ve hemşirelerin duyarlılıklarının belirlenmesi. Yayınlanmamış Doktora Tezi, İstanbul Üniversitesi Sağlık Bilimleri Enstitüsü, 2005.

22. Orak NŞ, Alpar ŞE. Hemşirelerin profesyonel değerleri ölçeğinin geçerlik ve güvenirlik çalışması. Clin Exp Health Sci 2012;2:22-31.

23. Şendir M, Acaroğlu R, Kanan N, Shonen R, Katajisto J. Bireyselleştirilmiş bakım ölçeği-hemşire versiyonu'nun türkçe geçerlik ve güvenirliği. 1. Temel Hemşirelik Bakımı Kongresi Kitabı, İzmir: Ege Üniversitesi Basımevi Müdürlüğü; 2010;129.

24. Suhonen R, Gustafsson ML, Katajisto J, Välimäki M, Leino-Kilpi H. Individualised Care Scale-Nurse version: A finish validation study. J Eval Clin Pract 2010;16:145-54.

25. Suhonen R, Välimäki M, Leino-Kilpi H, Katajisto J. Testing the individualized care model. Scand J Caring Sci 2004;18:27-36.
26. Suhonen R, Leino-Kilpi H, Välimäki M. Development and psychometric properties of the individualised care scale. J Eval Clin Pract 2005;11:7-20.

27. Bahar Z, Beşer A, Mızrak B, Bahçelioğlu D, Demirtaş D, Özdemir D, et al. Hemşirelerin karşılaştıkları etik ikilemlerin incelenmesi. J Anatolia Nurs Health Sci 2011;14:52-60.

28. Gül Ş, Duru-Aşiret G, Bayrak-Kahraman B, Devrez N, ÖrnekBüken N. Etik dersi alan ve almayan hemşirelik öğrencilerinin etik karar verebilme düzeylerinin incelenmesi. Turkish J Res Develop Nurs 2013;15:23-31.

29. Aydın Y, Dikmen Y, Kalkan SC. Ebelik öğrencilerinin hasta bakım uygulamalarında etik duyarlılıklarının incelenmesi. Çağdaş Tıp Derg 2017;7:168-74.

30. Aksu T, Akyol A. İzmir'deki hemşirelerin etik duyarlılıklarının incelenmesi. Turkish Clin J M Ethics-Law History 2011;19:16-24.

31. Dikmen Y. Yoğun bakım hemşirelerinde etik duyarlılığın incelenmesi. Cumhuriyet Hemş Derg 2013;2:1-7.

32. Park M, Kjervik D, Crandell J, Oermann MH. The relationship of ethics education to moral sensitivity and moral reasoning skills of nursing students. Nurs Ethics 2012;19:568-80.

33. Eraydın Ş, Albayrak K. Hemşirelik Öğrencilerinin Kişisel Değerleri ve Etik Duyarlılıklarının İncelenmesi. 14. Ulusal Hemşirelik Öğrencileri Kongresi. Kayseri, 2015.

34. Selçuk KT, Demir C. Hemşirelik bölümü öğrencilerinin etik duyarlılık düzeyi ve etkileyen etmenler. 14. Ulusal Hemşirelik Öğrencileri Kongresi Kitabı. Kayseri, 2015.

35. Kim YS, Park JW, Son YJ, Han SS. A longitudinal study on the development of moral judgement in korean nursing students. Nurs Ethics 2004;11:254-65.

36. Karamanoğlu A, Özer F, Tuğcu A. Denizli ilindeki hastanelerin cerrahi kliniklerinde çalışan hemşirelerin mesleki profesyonelliklerinin değerlendirilmesi. Fırat Tip Derg 2009;14:12-7.

37. Beydağ K, Arslan H. Kadın doğum kliniklerinde çalışan ebe ve hemşirelerin profesyonelliklerini etkileyen faktörler. Fırat Sağ Hiz Derg 2008;3:75-87.

38. Tazegün A, Çelebioğlu A. Çocuk hemşirelerinin etik duyarlılık düzeyleri ve etkileyen faktörler. İzmir Dr. Behçet Uz Çocuk Hast Derg 2016;6:97-102.

39. Lee LC, Chen $\mathrm{CH}$, Yang YO. The affect of gender on caregiving: A study of male nurses. Hu Li Za Zhi 2010;57:77-81.

40. Idvall E, Berg A, Katajisto J, Acaroglu R, da Luz MDA, Efstathiou $G$, et al. Nurses' sociodemographic background and assessments of individualized care. J Nurs Scholarsh 2012;44:284-93.

41. Aitamaa E, Leino-Kilpi H, Puukka P, Suhonen R. Ethical problems in nursing management: the role of codes of ethics. Nurs Ethics 2010;17:469-82. 